\title{
CHAPTER
}

\author{
AleXANDER BOGNER ${ }^{1}$ AND WOLFGANG MENZ ${ }^{2}$
}

\section{BIOETHICAL CONTROVERSIES AND POLICY ADVICE: THE PRODUCTION OF ETHICAL EXPERTISE AND ITS ROLE IN THE SUBSTANTIATION OF POLITICAL DECISION-MAKING}

At the beginning of 2002 the German parliament took a decision on the permissibility of embryonic research. The compromise reached had neither the compelling logic of the liberal position nor the moral consistency of the opponents of research involving the destruction of human embryos: it allows research on imported embryonic stem cells which originated before January 2002. The decision was preceded by a public discussion in talk shows and newspapers where, for a long period before the fundamental political decision, the most important arguments and positions on the question of the ethical legitimacy of stem cell research were debated. At the end of November 2001 the recommendations of the ethics councils were made available. The Nationaler Ethikrat (National Ethics Council) and the Enquete-Kommission 'Recht und Ethik in der modernen Medizin' (Study Commission on Law and Ethics in Modern Medicine) expressed the anticipated dissent in the commissions by formulating divergent positions and documenting them in separate votes. A similar situation occurred a little later in Austria. At about the same time as the German National Ethics Council was being established, the Austrian chancellor convened a bioethics commission which drew up a statement on stem cell research. As in the German case, competing positions were expressed and documented.

On the basis of this example of 'ethical assistance' to political decision-makers, we discuss in this chapter the following questions: Can one identify a social meaning of the advice provided by expert commissions under conditions of the absence of clarity? Or, more generally: What does the "new institutionalisation of morality" (Kuhlmann 2002) mean for the relationship between expertise and politics? And what follows from the disagreement of the commissions' experts for the legitimation of political decision-making?

Our chapter, dealing with this „new complexity in the relationship between science and politics“ (Weingart 2001a: 80), is structured in two sections. In the first section, against the background of the sociological tradition, we critically address the 
basic assumptions of the theory of reflexive modernisation concerning the role of expert knowledge in the face of new risks. In the second section we outline, in the form of a series of theses, some findings of our qualitative interviews with members of the Austrian Bioethics Commission.

\section{INSTITUTIONALISED DISAGREEMENT AND POLITICAL DECISIONS: CRIT- ICAL REMARKS ON THE THEORY OF REFLEXIVE MODERNISATION ${ }^{1}$}

Max Weber discusses the question of expert knowledge and political decision-making in terms of the relationship between the specialised German civil service (Berufsbeamtentum) and political leaders (Weber 1958). He is concerned that political action is subjected to an administrative-bureaucratic logic of its own, paralysing political initiative and influence. Although the 'leading spirit' of the politician depends on the technical knowledge of administrative experts, he also has to free himself from the administrative apparatus in order to make fateful decisions. How can the weights of the civil service, parliament and political leaders be balanced without either letting the bureaucracy inhibit the capability to decide or leaving unused the advantages of rational and specialised organisation?

In contrast to Weber, who demands the indispensable sovereignty of politics as opposed to the inescapable process of bureaucratisation, Helmut Schelsky sees the nature and task of politics in the functionality of technology. The state becomes a "technical state", where politics only has a fictitious capacity to take decisions (Schelsky 1965: 457). Weber's political decisions, as questions of fate, became bare matter-of-fact choices between different recommendations and expert opinions. Given the premise that the uncertainty of decision vanishes in the course of technological development, and that the best option according to scientific rules can be realised, politics becomes the executive body of expert reason.

In contrast to the above two authors, Ulrich Beck places the growing ambiguity, plurality and contradictoriness of expert knowledge at the centre of his analysis (Beck 1993, Beck and Bonß 2001). When new uncertainties appear and are recognised, the traditional-modern rationality, which is orientated towards efficiency and productivity, is split up into different, competing and contradictory rationalities. In the course of modernisation, side-effects are produced and spaces of non-knowledge are revealed which question modernisation itself. The controversial interpretations of (knowledgebased) risks reveal systematic insufficiencies of expert knowledge and prove that the expert's promises of security are exaggerated. Expert knowledge becomes both the stimulus and the medium of a struggle about the power to define. The quarrel between experts and counter-experts becomes part of the enlightenment of modernity about itself. In these conditions, argues Beck, political decisions cannot simply be taken at the behest of the experts and without public discussion and participation.

Today, hardly anyone would share the optimistic view that the side-effects and the recognition of non-knowledge will lead to the desired revision of the path of modernisation. We can observe a political-institutional pacification of previously central risk conflicts. Beck's counter-experts grew up, became institutionalised, and have been funded by public money and have developed their own modes of selection and hierarchisation. As the established interpreters of the deficits of modernisation, they are 
part of the dissonant background choir of modernisation. The struggle over the power to define has become a pluralistic debate.

In addition, Beck's optimism conceals some systematic reasons which imply a certain danger of misjudging the new political meaning of pluralism and dissent. Beck's theory of expert knowledge and modernisation is based on an ambiguous concept of risk, seeing it as a social construction but at the same time as a real threat independent of the observer or the discourse. This objectivist reading of risk as an attribute of technology has been criticised by Luhmann (1991) and other authors who also refer to a constructivist epistemology (Japp 1996, Tacke 2000). Luhmann argues that the concept of risk should not be reserved for the - albeit spectacular - potentials of danger and threat. In the concept of risk, different elements of the various processes of de-traditionalisation since early modernity intersect. In the course of the dissolution of traditional beliefs about fate and predestination, the future is no longer constructed as an extended present and new forms of coping with this new future, open to decision, have to be found. The immense significance of risk - in the sense of decision-making under the "pressure of contingency" (Japp 1992: 38) - refers to the gradual strengthening of a specific modern type of rationality. The aim is to act purposefully, rationally and in a calculating way in relation to the future, in order to realise new chances of action (Bonß 1995). In this respect risk has to be seen as a specifically modern case of an unrealisable imposition of rationality: we have to decide without knowing the 'right' solution or, to be more precise, with the certainty that there is no single, optimal solution.

This insight also leads us to a more critical assessment of the political significance of expert disagreement. If we cannot regard the decision about a (fundamentally) uncertain future as a result of superior knowledge and systematic scientific rationality, the decision comes to depend on symbolism and strategies. The traditional rationality of political decision-making is replaced by a kind of politics of rationality. Politics has to solve the problem of reconciling the societally influential idea of rationality with what has been seen of its way of dealing with uncertainty. Today, therefore, it is important for political decision-makers to make the public accept (on the basis of the formal granting of certain expectations concerning the process of the shaping of opinion) that it is possible to decide and decisions must be taken. One way of establishing a credible and convincing moment of decision is precisely by establishing a role for an institutionalised (counter-)expertise.

We have been able to observe this need to create a moment of decision in the course of the process of decision-making on the question of the permissibility of stem cell research. Although the statements of the expert commissions in Germany and Austria did contain hardly any new arguments as compared to the broad public debate, it was not considered acceptable for politicians to anticipate the experts' conclusions. The recommendations represented a decree that a political decision was now on the agenda. A political decision is legitimised only if it is assumed that it could have turned out differently. In short, politics in a sense relies on dissent. Although the commissions made clear the relevance of the topic and showed the possibility and necessity of regulation, they gave contradictory recommendations.

From the perspective of the political system this is quite functional: through the divergence of the expert's options, politics as decision actually becomes visible. If 
politics were just the execution of technical formulas or inherent necessities (as in Schelsky's concept), it would eventually disappear.

At the same time a transformation of the rationality of political decision-making takes place. In the German example, the decision about the permissibility of stem cell research was delegated to the 'sense of responsibility' or the 'conscience' of the members of parliament. In a similar way, in Austria the decision was handed over to the personal assessment of the minister who had to represent Austria's position in Brussels on the question of whether stem cell research, in the context of the EU's sixth framework programme, should be funded by taxation. In a sphere which is usually understood as an arena of superior reason, a scientifically supported and legitimised emotionality became the political rationality. Indeed, the arguments of the scientists and experts in the ethics commissions provide the necessary background knowledge and the patterns of legitimation. But the real decision takes place on a different level.

This does not mean that politics decides irrationally (in a value sphere outside expertise), nor that technical constraints determine politics. Hence, the relationship between science and politics cannot be represented adequately in the form of a model of dominance as described by Weber and - with the opposite normative assessment Schelsky. Rather, our interpretation suggests that we should understand this relationship as a form of mutual instrumentalisation. For politics, the dissonant expert discourse is a prerequisite for a successful maintenance of the ability to act. For science uncertainty and pluralism become characteristics of quality, especially concerning its role as a legitimising resource for politics.

From this perspective the dissent of the experts cannot be seen as a correction potential of modernisation. On the contrary: the current controversies about bioethics show in an exemplary way that the interaction between expertise and politics is a fundamental precondition for the establishment of the political capacity to act via the affirmation of the existing logics of procedure. Conflicts among experts not only express the limits of the traditional-modern way of dealing with new uncertainties; they also provide a way of coping with such uncertainties.

\section{THE PRODUCTION OF EXPERT DISAGREEMENT - THE CASE OF THE AUSTRIAN BIOETHICS COMMISSION}

In this section we will substantiate our conceptual considerations with some insights derived from an empirical perspective. We take a closer look at the Austrian Bioethics Commission's internal processes of decision-making, the political role of the commission's work and its recommendations for public policy. We concentrate mainly on the question of how the discussion in a group of experts results in manageable decisions and political recommendations.

For our analytical perspective it is decisive that we do not consider the process of generating an expert vote mainly as a process of general understanding and agreement, in which a "peculiar non-coercive force of the better argument" ("eigentümlich zwanglose(r) Zwang des besseren Argumentes”) (Habermas 1971: 137, trans. by authors) can unfold itself. Rather, our analysis is inspired by concepts originating from strategic organisation analysis as formulated by Michel Crozier and Erhard Friedberg 
(Crozier and Friedberg 1977, Friedberg 1993). This approach stresses that action within an organisation has to be understood in terms of the strategies and resources of action of concrete (primarily collective) actors in the context of organisational structures, rules and "games". Thus, we place the processes of negotiation and compromise-formation as well as the formal and informal structures of coordination at the centre of our analysis. Processes of decision-making cannot simply be explained by reference to a superordinate societal structure, but have to be understood in the context of the particular "local order" (Friedberg 1993). In a similar way, we draw on sociological analyses of micropolitics within organisational processes and decisions (Küpper and Felsch 1999, Küpper and Ortmann 1992, Ortmann et al. 1990). ${ }^{2}$ From the perspective of political science, Nullmeier et al. (2003) formulate an ethnographic view of everyday action and interaction in political institutions below the level of macro-structures called 'micropolicy analysis', which shares a similar perspective, in some respect, with organisational sociology. With respect to our subject, our thesis is that the formulation of the experts' votes cannot be understood as an uninfluenced 'free' shaping of opinion, nor a process determined by political macro-structures with an outcome determined beforehand. Rather, we postulate that it is an organised procedure of negotiating expertise which leads to the production of politically manageable dissent.

The Austrian Bioethics Commission was constituted in July 2001, one month after the German Chancellor Gerhard Schröder established the German National Ethics Council. The legal basis of the appointment of the Austrian commission was an order enacted by the Austrian Chancellor Wolfgang Schüssel. The commission has the task of advising the chancellor on bioethical questions and providing recommendations in relation to the challenges confronting the government as a result of biomedical progress. In the latter case, the commission has to deal with questions raised by the political system. Both the experts and the government single out two roles of the commission: first, policy advice; and second, the initiation and intensification of public discourse about bioethical issues. This means that the commission has to provide recommendations on current trends in the biomedical field, and also has to be a kind of early warning system, a discussion forum able to identify emerging or imaginable societal consequences of biomedical progress as a central theme. Furthermore, it is supposed to engage with an intensifying public debate. Even the commission members considered it a weakness that the commission did not set the agenda. But up to now the commission has acted in accordance with the day-to-day political agenda, to the extent that reactions to political inquiries have been central to its work. The commission's discussions have been aimed at developing recommendations and opinions on current problems (like stem cell research) and other biomedical issues which have been neglected in Austria, such as the ratification of the Convention on Human Rights and Biomedicine of the Council of Europe and the implementation of the Council Directive on the legal protection of biotechnological inventions.

The interdisciplinary Austrian Bioethics Commission consists of 19 experts, 15 men and four women (the German National Bioethics Council has 25 members). There are seven medical doctors (fields of activity: gynaecology, haematology, psychiatry, oncology and pathology), three human geneticists, two lawyers, two philosophers, two theologians, one sociologist, one computer scientist and one representative 
of the biotech industry (Novartis). In terms of different world views or 'ideologies', the commission is distinguished by considerable heterogeneity: there is a Catholic theologian and an atheist, conservative medical doctors, and convinced social democrats. The members of the Austrian commission were appointed by Chancellor Schüssel, and the most important criterion of appointment was - according to the official statement - their specialised knowledge (Bundeskanzleramt 2001). But in fact nobody knows why exactly these 19 experts were appointed and who advised the chancellor. Even the members of the commission themselves cannot explain which criteria were decisive. The lack of transparency of the process has been repeatedly criticised, as has the fact that the commission was created as a pure expert council (Gottweis 2001).

The Austrian Bioethics Commission is therefore under considerable legitimation pressure in several respects. Criticisms from different organisations of disabled people culminated in the founding of a (counter-)commission, the Ethikkommission FÜR die österreichische Bundesregierung (Ethics Commission FOR the Austrian Federal Government, original emphasis), just a few months after the expert commission had been founded. Its name indicates its purpose - to be an advisory body for political decision-makers. It was explicitly set up to represent persons affected by the political decisions about bioethical matters of dispute, and not as a pure assembly of academic expertise like the 'official' bioethics commission. However, the pressure of legitimation did not only pertain to the process of appointment and the lack of representation of important social groups, but to the general question of how to institutionalise political advice in the form of expert commissions. ${ }^{3}$ Thus, the alternative commission does not only see its task as providing 'better' or 'counter-balancing' expertise for the government, but also involving the broader public in the process of shaping a political opinion and making decisions.

Participatory forms of formulating political objectives do not have a strong tradition in Austria, in contrast to countries such as Denmark, where commentators see the most far-reaching efforts to involve the public in decisions on issues of bioethics (see Joss and Durant 1995). However, we can observe a change in attitudes or an attempt to broaden the debate in Austria. For example, most recently and for the first time, a BürgerInnenkonferenz (citizens' conference) ${ }^{4}$ took place, with a thematic focus on genetic diagnostics. ${ }^{5}$ Like other initiatives in Europe (see Joss and Torgersen 2002), its goals were twofold. On the one hand, it was intended to stimulate a broad public discussion. On the other hand, its proposals, votes and demands were designed to influence political and economic decision-makers. The BürgerInnenkonferenz was shaped according to the Danish concept of the consensus conference with its aim of democratising technology policy (Winner et al. 1997). In this way, the BürgerInnenkonferenz was designed to be a form of institutionalised advice, in a sense competing with any expert committee. It remains to be seen whether it will be able to do this in practice. Certainly, it is unlikely that this kind of participatory bioethical advice will develop into a general challenge to expert committees, and that it will gain broad influence in state politics. Possibly, Austrian politics will exploit the results of institutionalised public participation efforts as a source of more reliable information on public opinion, because they promise to deliver deeper and more complex and authentic views as compared to opinion polls. ${ }^{6}$ 


\section{Ethical Decision-Making Goes Pragmatic: The Issue and Subject of the Stem Cell Debate}

So far, we have concentrated on the composition of the Austrian Bioethics Commission and on a broad outline of the context of its institutionalisation. We now turn to the internal procedures designed to provide ethical expertise. Since all our remarks are related to the recommendations of the commission on the moral tenability of stem cell research, we shall begin by characterising different positions within the commission in more detail. This recommendation (entitled Stem cell research in the context of the EU's sixth framework programme research $)^{7}$ dealt with the controversial issue of whether or not Austria should finance stem cell research in the context of the EU's sixth framework programme (2002-2006). The resolution of the Bioethics Commission amounts to six pages, and the text is divided into two parts. The first part (two and a half pages long) presents a text that was unanimously agreed upon. In this part the experts emphasise that, from an ethical point of view, it is inadvisable to encourage exaggerated or premature expectations of a cure for any disease. In addition, the medical relevance and currently increasing importance of adult stem cells is emphasised and so the commission welcomes the decision of the Council of Ministers of the European Union to prioritise funding for research on adult stem cells. The Austrian commission also agrees unanimously with the European Parliament's decision to deny funding for reproductive cloning, the production of embryos for research purposes, and the modification of the genetic heritage of human beings.

This first part of the commission resolution is characterized by an expressly declared consensus within the group about the ethical difficulties arising from research with embryonic stem cells. It is followed by divergent judgements concerning the morality of doing research with embryonic stem cells, which are represented by the positions A and B. Position A supports funding research for embryonic stem cells, but recommends that strictly defined conditions have to be met, for example high-level peer review. In addition, only those stem cell lines are to be used which already existed before a given date (according to the corresponding regulation in Germany), so that the destruction of supernumerary embryos created via IVF treatment is not encouraged for purposes of stem cell research. Position B opposes the encouragement of stem cell research. Unintended consequences and the potential dangers resulting from the liberalisation of research using human embryos are emphasised. Following the well-known 'slippery slope' argument, it is claimed that in the end this encouragement will lead almost inevitably to liberalising embryonic research or even lead to the deliberate creation of embryos for research purposes. This trend would inevitably result in an increased societal acceptance of the availability of, and consequently the capacity for, the instrumentalisation of human life. Eleven members assented to Position A, while eight voted for the more sceptical position B.

How did such partly unanimous, partly divergent recommendations come into being? Which processes of negotiation, persuasion and compromise formation took place? What coalitions were formed? Which strategies were followed? What roles did different kinds of 'scientific knowledge' and divergent forms of expertise according to the respective disciplinary backgrounds play? And last but not least: can we consider ethical recommendations to be a form of scientific policy advice at all? 
In the following we will present the preliminary results of our empirical study on the production of expertise by the Austrian Bioethics Commission. Our analysis is based on semi-structured face-to-face interviews with 18 of its 19 members. In a second step, we will turn to the relationship between the 'commissionary expertise' and the political reasoning and legitimising efforts in public argumentation. What does disagreement among the 19 experts entail for the substantiation and justification of the decision about whether or not stem cell research should be allowed? What role did the institutionalisation of bioethical expertise play for the system of political decisionmaking?

Thesis: In the discussion process, fundamentalist points of view are marginalised. From the very beginning we can see a strong 'pragmaticisation' of decision-making. Rather than deep reflection, producing results is the main consideration.

Because they have to address concrete questions relevant to day-to-day politics, bioethics commissions hardly provide any room for fundamental debates about ethical questions and positions, and no room at all for deeper questions such as the conceptualisation of ethics as such. Therefore, the commission gets into a paradoxical situation where there is little clarification of its subject. This does not imply that the fundamental ethical contexts of the relevant positions no longer play a role. The interviewees often pointed to different ethical traditions linked to the different ways of arguing. However, such differences were kept at a low level during the discussions within the commission. In other words: an ethics commission does not function like a philosophical seminar, where participants discuss fundamental ethical considerations and the sustainability of different theoretical approaches (such as utilitarianism, deontological positions, etc.) with respect to certain biomedical questions. It is not the strength of the ethical argumentation that is decisive, and there is no debate on fundamentals. Rather, the question is whether a certain 'ethical basis' or orientation gets support from a majority. This does not imply that unconvincing ethical positions will in general get support from a majority. Indeed, there is no serious assessment of how convincing divergent ethical positions are in practice - this is what we mean by 'pragmaticisation.' Additionally, a given position does not need to be founded in an explicit ethical argumentation. Rather, it is expected to result from a convergence with certain cultural Leitbilder (ideals of how to live, body images, etc.), which do not need to be present in a reflected way. From this perspective, an ethical argument supported by a majority does not imply a superior cognitive quality; rather, it shows a lucky convergence of societal dispositions and philosophical reflections. Last but not least, it would be unrealistic to expect an explicit ethical foundation for single positions to be provided by a bioethics commission primarily consisting of 'ethical lay persons' and working on a tight schedule.

Within the commission, a text on the issue of stem cells was proposed at an early stage. One member of the commission drew up this text on his own. The debate centered on this text, and it served as a trigger for discussions which ultimately led to a differentiation of positions. This is also reflected in the final paper. The more explicitly critical position B reads to a considerable extent like a comment on the other position. 
Several members of the commission expressed their regret to us about the lack of depth of the ethical discussion. There are two sets of reasons for this 'pragmaticisation of the ethical decision-making process.' First, the commission was under pressure from the political sphere, because Austria had to take an early decision on where to position itself in the deliberations on the sixth framework programme of the European Union. However, it was not only external pressure from the minister responsible, Elisabeth Gehrer, or political influence that made it necessary to come to a swift decision; rather, this was (also) due to the genuine strategic self-interest of the commission. Had they delayed their statement by prolonging the debate, this would have resulted in a self-disempowerment of the commission. If the findings had been issued after the date relevant for the political decision, it would only have amounted to a critique or acclamation issued after the decision had been taken. The commission's own claim to advise the politicians would not have been substantiated, and the commission would have jeopardised its own function and performance.

Secondly, sacrificing the fundamental ethical debate was also significant for productivity within the commission. It made it possible to avoid potential conflicts, and it enabled the formation of coalitions between members otherwise supporting very different fundamental ethical positions. Excluding basic questions by pursuing ethical pragmatism increases the capacity to come to unanimous decisions among different positions.

The Politics of Ethics - Ethics as Micropolitics: The Deliberation Process Within the Commission

Thesis: The decision-making process within the ethics commission can be understood not so much in terms of a free discursive coordination, but rather as a 'micropolitical' network of interactions. Major explanatory factors are the actors' strategies and coalitions between the members of the commission, and also processes of power and opportunities to influence the process.

The aim of the members of the ethics commission is to 'get a voice' themselves, to be heard in politics and among the public. They all consider a cacophony as possibly leading to a loss of influence, both for individual positions and for the commission as a whole. Regarding their aim, the strategy for any individual member cannot be to formulate an argumentation that is as consistent and stringent as possible. Rather, it is important to gain influential 'coalition partners' within the commission. In order to find them, one does not have to develop a sharply profiled position on ethics; one has to act strategically. One has to be prepared to find common ground among different positions, or to make do without putting forward one's own arguments if this would provoke a new round of fundamental debates. One needs to reduce oneself to a fictional canon of 'expressables', to the set of (internationally established) patterns of argument which include all 'acceptable' arguments. The members consciously exclude decidedly individual positions which would not find majority support within the commission or be suitable to serve as a basis for coalitions. 


\begin{abstract}
There was a long discussion, and then eleven members of the Bioethics Commission agreed on a positive recommendation. Eight members, of which I was one, rejected that position. We had very different reasons for doing so, and I wasn't really able to explain what my reasons were. I have two reasons which aren't specified in the paper itself. Well, you could even say I had a third position, or something like that... My main reason was that I feel very uncomfortable, because of my conception of democracy, if the EU Commission forces member states to take decisions on matters about which individual states have not had a proper debate - and when the Commission itself is well aware of this fact. Austria has not really discussed the question of research on human embryonic stem cells. (...) In the UK a debate has been in progress for the last twenty years, they have the necessary laws and regulations, and the British can justify a decision to conduct research on human embryonic stem cells because they have thought it through and discussed it adequately. If we decide to do the same just because we don't want to be left behind economically, I have serious ethical reservations. I would say: what are we going to sacrifice next? (Commission Member II). ${ }^{8}$
\end{abstract}

During the deliberation process, a 'sub-politicisation' takes place in the shape of a loss of importance of 'official' political arenas to the benefit of smaller areas of deliberation that were not decided on beforehand. The discussion keeps moving out of the 'big' commission into meetings of working groups made up of 'likeminded people,' and ultimately to talks and attempts to find agreement in a fully informal setting (such as a private talk in a restaurant). The interviewees described the formulation of a group position as a prolonged process involving tactical moves, strategic considerations, the reaching of multiple compromises etc.

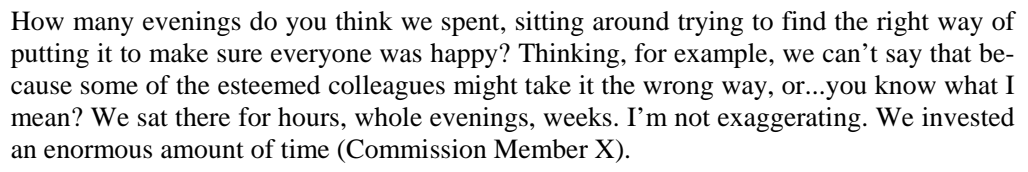

The supporting texts for position A and position B show a strategic element. B can easily be understood as a compromise between a religious fundamentalism and the kind of scepticism highlighting the inconsistency and the temporal limitation of the safety measures supported by A. There is a range from a Catholic moral theologian insisting on the absolute ontological, moral and juridical status of an embryo, to a patho-physiologist criticising, from a natural science point of view, the concentration of research on embryonic stem cells only. However, ontological and metaphysical arguments are placed in the background. Instead, a risk assessment highlighting elements of societal ethics is put forward. Second, position B refers, to some extent, to the 'slippery slope' argument, assuming that any form of liberalisation of stem cell research will lead to the production of embryos for research, and, therefore, will foster an instrumental attitude toward human life. In other words: position B omits a determination of its position by means of fundamental ethics, which would have to go with a considerable sharpening of the argument. This is explicable in strategic terms. Since more members obviously supported position $\mathrm{A}$, it would have been an additional weakening for position B if it had further split up. From the point of view of content, however, such a split would have been logical, since within position B the tendency to fundamentally reject the issue is combined with the tendency, from the perspective of research, to temporarily reject it. 
Excursus: The Pitfalls of Strategic Action - Unintended Results of Actions

The statement of the bioethics commission cannot be understood simply as a strategically balanced compromise. Unintended results of actions impact both the result of the group's internal deliberations and the political decision-making. Therefore, the result of the deliberation in its concrete form cannot be predicted.

The example of the deadline regulation is instructive with regard to unintended results of strategic action that have an impact on the level of political decision-making. In the commission statement, position A argues for restricting the use of stem cells to those lines existing prior to a certain deadline, in order not to stimulate the production of supernumerary embryos by IVF. The German Ethics Council had previously issued a similar regulation. In the Austrian case, this regulation was proposed by a member of the commission who himself, for ethical-practical reasons, did not consider the regulation to be necessary. Rather, the intention was to support position A by means of a partial acceptance of the rejection by more sceptical members of the commission. This tactically motivated proposal of a deadline, however, developed during the further discussion within the commission into an important point of identification for the fraction of sceptics. In the face of this example, the warning of a 'slippery slope' seemed to be substantiated in a paradigmatic way. According to this view, the deadline regulation could represent, so to speak, a way of making research possible after all. Given the assumption that the quality of the stem cell lines developed prior to the deadline would turn out to be insufficient, one would not be able to avoid slippage up to the complete liberalisation of embryo research (and, hence, for the liberalisation of therapeutic cloning). There would be no place any more for ex-post fundamental ethical concerns. Hence, the deadline regulation served - against the underlying intention - not only as a catalyst to crystallise the sub-group of critics. In the end, it also developed into a central lever for politicians wishing to reject stem cell research by highlighting the lack of safety guarantees.

\section{A 'Culture of Productive Disagreement' Rather Than a 'Battle of Cultures': Dealing With Disagreement Within the Commission}

Thesis: The enforcement of ethical positions which are not revised fundamentally in the process of bargaining continues to be a subject of strategic action. The anticipated impossibility of reaching agreement has to rely on a professional 'culture of productive disagreement.'

Our previous remarks should have made clear that we do not interpret the commission as a theatre stage on which a spectacle of bioethics takes place according to a previously well-known script. Even if the recommendation of the commission does not represent the result of a free, unconstrained discursive interchange dominated by the better argument but rather a result of strategically oriented action, of coalitions, and of unintended consequences, it should be clear that the concrete result is not predetermined. In the context of our discussion about the function of dissent, we are more interested in the question of whether the assumption of an overall consensus within the expert group could be realistic. However, this question can definitely be answered 
only negatively. All members anticipated that they would be unable to agree on the ethically challenging issues.

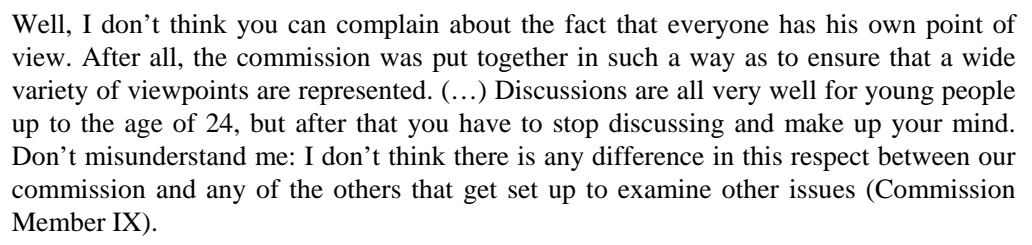

Well, I don't think you can complain about the fact that everyone has his own point of view. After all, the commission was put together in such a way as to ensure that a wide variety of viewpoints are represented. (...) Discussions are all very well for young people up to the age of 24 , but after that you have to stop discussing and make up your mind. Don't misunderstand me: I don't think there is any difference in this respect between our commission and any of the others that get set up to examine other issues (Commission Member IX).

Not only is it anticipated that the members of the group will disagree with each other, they are actually expected to do so. Disagreement seems to be a kind of guarantee of the quality of expert discussions. It is, firstly, an inevitable consequence of the Chancellor's appointments policy, which has to be seen to be credible, and, secondly, an inevitable consequence of the specific professional socialization and individuation of the experts, who are usually university professors with the corresponding habitus.

Every national debate between experts is also embedded in an international context. The orientation towards influential discourses, which in the end means bringing into play established models of argument and existing basic positions, is very important in the production of an output with a certain content. This awareness of the discursive pre-structuring of debates in expert bodies also involves being aware that the important thing for the concrete result is less a matter of weighing up theoretical considerations and more a question of constructing majorities in a strategic-political way. Therefore, the degrees of flexibility present in an expert discourse relate less to the cognitive-normative level than to the level of micropolitical action.

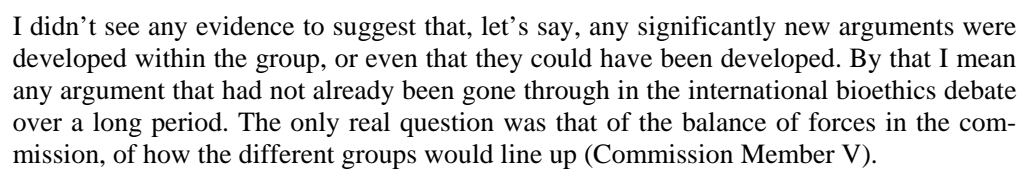

I didn't see any evidence to suggest that, let's say, any significantly new arguments were developed within the group, or even that they could have been developed. By that I mean any argument that had not already been gone through in the international bioethics debate over a long period. The only real question was that of the balance of forces in the commission, of how the different groups would line up (Commission Member V).

However, the fact that debates in the commission are conducted in accordance with arguments which are established and already worked out does not mean that the positions of the different groups are predominantly characterized by logical stringency and normative consistency. The Bioethics Commission's position is not just a local reflection of the range of ethical theories available and of views held by different parties on the national and international level. In the final analysis, the 'mix' of individual positions that emerges at the end depends on the concrete processes of groupformation. Normative consistency is far from being the primary structuring principle. Rather, the opposing positions seem to be derived from a diffuse but basic position which, in the course of the negotiations, is enriched by other arguments that have the capacity to command majority support.

\footnotetext{
Well, if you look at where it originates, what happens is simply that the arguments attach themselves to these basic positions like burrs, they just fit. And then those who are in favour put forward one view ... they just try to strengthen their position with a canon of arguments. And the other members of the commission try to make other arguments sound more convincing, and in the end what you've got on the table are a couple of positions that are more or less supposed to reinforce each other - or not, as the case may be. The whole thing grows, like strudel pastry (Commission Member IV).
} 
The desire to be politically influential or to provide a forum for public debates needs, even if not real consent, at least a clear setting out of the main positions. This implies that the members feel a certain pressure on themselves to reach an agreement. Only then, as we have already argued, does the necessity arise for 'micropolitical' interactions like reaching a compromise, building coalitions, maneuvring. Strengthening one's own ethical position remains the highest aim among the commission members; there is no interest in maximizing one's influence at any price, for instance by moving to the majority fraction. On the contrary: a (strategically motivated) abandonment of ethical positions will take place only if the fundament of the respective ethical orientations remains unchanged - in the result (for example, when the Catholic theologian joins a position whose opposition to stem cell research is not determined by theological-ontological arguments but founded in a pragmatic way).

The interaction about divergent positions within the commission takes place in the context of a 'consensual dissent culture.' The commission practice even leads to a defusing rather than to sharp profiling of the different positions. The interviewees said they explicitly wanted to avoid a 'battle of cultures' within the commission's work. The condition required for this productive disagreement is a generalised willingness to cooperate, a kind of professional friendliness. These are elements of a widely accepted academic identity and help individuals to reflect on the contingency of their own position.

\begin{abstract}
This is one of our exercises: to explain the premises and background assumptions of your own viewpoint in such a way that the person you are trying to convince can at least empathize, and doesn't experience the exchange as a battle of cultures (Kulturkampf). That's not such an easy thing to do, even among the members of the commission. You have to be objective and friendly at the same time, because these people all know each other. Some of them have close professional ties and regular contact with one another. And it's also an interesting learning process, taking a different view on a question you think is very important in a commission, and then the next day in another context continuing to work on a perfectly friendly basis with the same people. You have to practise quite hard to get that right (Commission Member IV).
\end{abstract}

In this passage, one can see that the orientation towards 'productive disagreement' is largely explained in terms of the close internal connections within the circle of experts, and so in the final analysis in terms of the fact that the world of experts (especially in Austria) is small and that the people who make up this world are dependent on one another. In the following extract from an interview, the explanation offered has more to do with professional socialisation: in the course of time, every scholar is forced to recognize the contingency of positions from which scientific observations are made and of scientific knowledge.

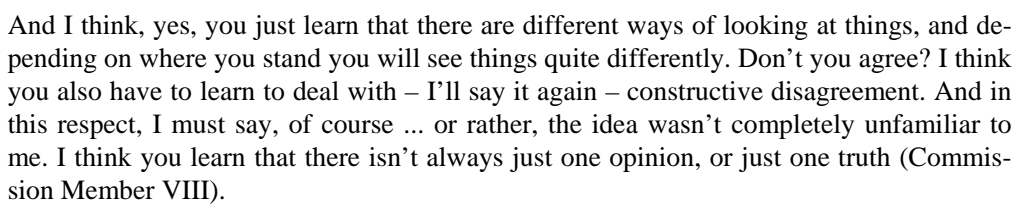

One thing which obviously belongs to this expert culture is the critical deliberation and balanced reflection rather than the sharp profiling of one's own ethical position. Last but not least, this leads to the impression that both positions look very similar in 
relation to the structure and mode of argumentation - even if contradictory recommendations are given as a result.

The cooperative manner of working within the commission is widely illustrated by the fact that members were partly willing to work with representatives of the 'antagonistic' position in order to enhance formulations and arguments. It is most important for the experts, we would argue, to secure the professional authority and the persuasiveness of the whole commission in the eyes of both politics and the public. Shortterm political influence is only a secondary objective. (A badly organised counterposition would have been useful for one's own fraction in the public debate at first glance, but this consideration implies that the political enforcement of one's own position soon reaches its limits).

In the long run this way of acting seems to be absolutely functional from the perspective of the expert commission. Ensuring the scientific authority of the commission is in general an important prerequisite of remaining influential in the field of policy. If the commission had disqualified itself in the eyes of the government and the public by a lack of accuracy or implausible arguments, this would have reduced the opportunities for influence of the individual positions represented. This kind of risk exists not only for individual members but also for the commission as a whole. These considerations lead us to the conclusion that disagreement both calls for and enhances the capacity to cooperate. Due to reasons of maintaining the authority of science, it is necessary not to blame the 'ethical enemy.'

\section{"Ethics is Dynamic": The Relationship Between Knowledge and Values}

Thesis: Bioethical recommendations are bound to refer to the context of specific scientific facts. This technical knowledge, however, requires interpretation before it can become significant for ethical consideration. For this reason it makes no sense to differentiate strictly between (objective) knowledge and (subjective) values.

Profound knowledge of current biological and medical discussions is considered a basic precondition for a well-founded recommendation by all members of the commission. How to assess the therapeutic potential of human embryonic stem cells? How to assess their potential to develop and differentiate themselves? Is it necessary from a scientific point of view - to judge between the protection of the embryo and research freedom, in other words, are the therapeutic hopes connected with stem cell research realistic at all?

On this account, the significance of the current research findings becomes a subject of interpretation within the commission, in the process of ethical deliberation and bargaining between positions. An important question at the beginning of the discussion which is relevant for all members, natural scientists as well as social scientists, might be: does the latest article in Nature, in which analogies from experiments with mice are drawn to human embryonic stem cells, promise too much? In an attempt to base the ethical decision on a solid and 'value-free' foundation in this way, the publication policies of the influential peer-reviewed journals or the capability of interpretation of the participating natural scientists may influence the ethical judgement to a 
certain extent. From a more formal perspective, one can certainly characterise this as a division of labour between the different disciplines within the commission. First, at the beginning of a new topic, human geneticists and medical doctors from various fields give a short overview of the state of international research. Next, the lawyers inform their colleagues about the juridical regulations on the national as well as the European level. However, it would be wrong to assume that this kind of division of labour could be assigned to the bargaining processes - and, hence, to presume unreflectedly a differentiation between knowledge and values. Such a fallacy is obvious in the case of bioethics commissions because the phase of ethical judgement seems to follow after a phase where technical knowledge is arbitrated by the natural scientists. However, after careful consideration it is quite evident that the facts are not given first, after which the assessment follows; nor is it the case that scientific facts are evaluated according to individual preferences. In reality, knowledge and values are indistinguishable in this process. What the individual members or the whole expert group accept to be valid scientific or technical knowledge (in other words: real facts) is in fact subject to interpretation. In reality, the social as well as the natural scientists are unable to decide whether the articles published in renowned peer-reviewed journals are fully in accord with the relevant quality factors. A deeper investigation about their scientific quality would take far too long. And even if such an investigation were possible: in the current phase of research, analogies and extrapolations are necessary to provide a careful assessment of the feasibility and the potential benefits of stem cell research. And even if it were possible to state these issues more precisely, one has to remember that current knowledge can become outdated very fast. In other words: the scientific facts are put visibly into perspective in multiple ways. What is accepted as a real fact depends on the factual knowledge, the work, and the form of presentation of the participating scientists, and so it depends on the individual assessment of the facts presented, a process which is essentially interlinked with personal dispositions. These dispositions are defined as a bundle of imaginations and expectations that governs the way of perceiving and interacting. In this way dispositions are interlinked with societal discourses, 'ideologies' and so on, and they in turn influence and shape these structures. In the concrete case, the idea of dispositions means that the acceptance of something as a fact also means a judgement about the credibility of the experts who provide the information, or a view about the relevance of a specific scientific and academic tradition which is well-defined against others, and so on. Factual knowledge, from this perspective, becomes a product of complex social bargaining processes. This does not imply that in ethical discourse all knowledge is relative or that values dominate knowledge. Of course, an ethical assessment of biomedical practices cannot work without medical and human genetic knowledge, which defines a specific problem as relevant to a decision. However, the dependence of ethics on science goes further. According to the statements of different experts, ethical expertise is dynamic: ethical considerations depend on the current state of scientific research in the field of genetics and biomedicine.

Ethics has something dynamic about it, it's a process in which, because knowledge is always advancing (and that's the basic problem, this growth of knowledge), one's view of the consequences can change because there are other consequences, or the consequences can be better controlled, or whatever it may be. So, it is unbelievably dynamic. And I 


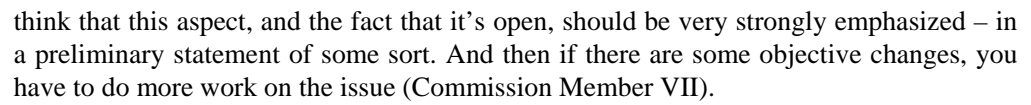

This element, the idea of knowledge as something incomplete and provisionally acknowledged, contributes to an awareness that the question being addressed is in principle open and temporary. At the social level, this awareness of the provisional nature of all expertise tends to defuse conflicts. As a result, the culture of expertise described above as 'productive disagreement' becomes possible.

So much is in flux, quite simply as far as the state of research, the state of empirical research, is concerned, that you can't easily adopt any kind of fixed ... or rather, that there's absolutely no need to defend any kind of fixed position whatever the cost (Commission Member X).

That natural scientific knowledge is dependent on interpretation makes it plausible that the attachment of the commission members to the two positions cannot be traced back to disciplinary boundaries or to the distinction between the natural sciences and the humanities (for example: scientific belief in progress versus theological scepticism). Position A was in large measure developed by a theologian on the basis of ethical deliberations. It was supported by human geneticists, less so by medical doctors. Position B was supported by the Catholic moral theologian, lawyers and philosophers, the haematologists and the pathologist - almost the whole spectrum of the disciplines represented in the commission. The sceptical position of the medical doctors, for example, was influenced by the unredeemed promises of the benefits of biomedicine (for example, of somatic gene therapy) and by their own experiences with (animal or human) adult stem cells. Thus especially the medical doctors who have specialist research experience and have an unchallenged high reputation in the commission took a particularly critical position.

At the same time, the thesis of a close link between knowledge and values gives us a possible answer to another question. It is often asked whether bioethics commissions are a form of scientific policy advice at all. Usually this questioning of bioethics is countered with reference to the scientific status of ethics itself. We do not want to deny this, but from the standpoint of the sociology of knowledge such a question is itself questionable. The commission members move on winding paths through claims and constructions of knowledge which cannot be separated from preferences and values and their modifications, and after a prolonged phase of debate, argument and negotiation they come to different positions - what could be more scientific?

\section{CONCLUSIONS: DISSENT, EXPERT OPINION, AND POLITICAL DECISION-MAKING}

After the Austrian expert commission had published its divergent recommendation on the case of stem cell research in May 2002, the minister responsible, Elisabeth Gehrer, went to Brussels and voted against the funding of research in the field of stem cell research. This means that she followed the recommendation of the explicitly researchcritical minority (Position B). But her statement also referred to the arguments of Position A. The minister argued that so far there were no guarantees on a European 
level that the deadline regulation voted for in Position A could serve as a morally acceptable form of stem cell research.

Not surprisingly, the commission members have taken very different views of this political decision. While those who were in agreement with Position B feel validated in their ethical judgment and welcome the decision, some representatives of Position A suspect that the political decision was influenced by different stakeholders (first of all the Catholic church) rather than by reasonable and objective considerations. However, all experts agree that the political function of the bioethics commission is (and should be) primarily a consultative one. No member of the commission considers the ethical recommendation as an authoritative instruction for the government to decide in a specific way. In the light of fundamental expert disagreement, traditional ideas of an advanced expert rationality or purely rational expert judgements that create inherent necessities for politics are not convincing any more. The bioethical experts, the politicians and, last but not least, the public know this to be the case - and it can be seen in the inability to agree within the expert commissions.

The divergent recommendations of the bioethics commission did not lead to a lack of legitimisation for the political decision. Against the background of the result of the ballot, which produced only a narrow majority (and this has a meaning only on a symbolic level), both fundamental options were open to the politicians. Moreover, the rejection of funding stem cell research could be plausibly substantiated with reference to both the pro and the contra position. In any case, the ongoing necessity for a political decision came to the fore. The scientific advice did not reduce the political autonomy of the decision. Politics could refer both to the expert knowledge on which the decision was based, and avoid the suspicion that it had acted without expert authority or decided in an irrational manner. The expert dissent did not result in discussions about new forms of political decision-making - for example by participatory instruments of policy advice.

Nor does expert disagreement pose a threat to the commission members themselves. Even though it is rational from an individual expert's point of view to try to maximise one's own 'ethical faction' by acting strategically, in case of doubt experts prefer to ensure the 'legitimatory surplus' of science, the legitimacy of their professional authority, and their expert status rather than to maximise short-term political influence. Even though the ethical interaction processes display the characteristics of a 'micropolitical' network under the constraints of coalition building, the appointment of the bioethics commission in an era of permanent expert dissent does not mean that the boundaries between scientific expertise and decision-making become blurred (see Latour 1999; and, with a focus on the relationship between expertise and the public, Nowotny et al. 2001). Rather, the example of the bioethics commission shows that the "scientification of politics" does not mean a depolitisation of decisions and factual issues, or a rationalisation in the broader sense of manufacturing a lack of ambiguity by insisting on consent and subsequent imperatives to decide (Weingart 2001b). Especially in bioethical debates, expert disagreement is obvious and permanent. It would be wrong to understand expert dissent as politically dysfunctional. On the other hand, "politicisation of science" does not mean a complete replacement of discourse by strategy or the complete metamorphosis of scientists into political actors. The limits 
of this politicisation of science are set by professional and scientific policy considerations.

It is another question whether it is helpful to analyze the current boom of scientific policy advice from a perspective proposed by systems theory, which draws the boundaries between science and politics according to unambiguous codings related to specific systems (see Luhmann 1992; Willke 2003). However, our example shows that, on the micro-level of structuring individual actions and interactions, the divergence between politics and science cannot be understood in terms of substantially different types of rationality, for example between forms of action seeking agreement and truth, on the one hand, and powerful strategic action on the other. Micropolitical theories of strategic organisation analysis teach us that every kind of action in the context of organisations, institutions, networks etc. involves coalition building, compromise formation, processes of negotiation and strategic action. However, strategic organisation analysis as well as micropolitical approaches also need to ask how actions are embedded within specific contexts, whether shaped by 'system-specific' or professional frames. These systemic frames come to the fore in divergent aims governing these actions. While it is the 'rationale' of the political system to maximise power by increasing the capacity to act and to put forward reasons in order to justify political decisions vis-a-vis the public, science concentrates on protecting its professional authority and claiming to provide implementable expert knowledge.

${ }^{1}$ Institut für Technikfolgenabschätzung der Österreichischen Akademie der Wissenschaften, Vienna, Austria

${ }^{2}$ Institut für Sozialforschung an der Johann Wolfgang Goethe-Universität, Frankfurt am Main, Germany

\section{NOTES}

1 For more details, see Bogner and Menz 2002.

2 For the differences between the concept of micropolitics and the strategic organisational analysis, see Friedberg 2003.

3 Political commentaries in different Austrian newspapers criticised the fact that only experts were appointed to the commission, see Gmeiner and Körtner 2002: 167ff.

4 The title of this conference was Genetische Daten: woher, wohin, wozu? (Genetic Data: Where from? Whither? What for?). The organiser was a public relations agency, and the conference was financed by the Austrian Council for Research and Technology Development.

5 This was the first citizens' conference concerning a bioethical topic. A consensus conference on the topic of climate change was carried out in Austria in 1997.

6 Our ongoing project entitled Bioethical decision-making and political legitimation. Citizen's participation and Bioethics commissions as instruments of policy advice in Germany and Austria addresses similar questions. This project is financed by the German Federal Ministry of Education and Research and started in May 2004.

7 The full text is available at http://www.bka.gv.at/bka/bioethik/englisch/index_empfehlungen_engl.html.

8 The following quotations derive from interviews with the members of the Austrian Bioethics Commission conducted by Alexander Bogner and Erich Griessler (Institute for Advanced Studies, Vienna) in autumn 2002. 


\section{REFERENCES}

Beck, U. (1993), Die Erfindung des Politischen. Zu einer Theorie reflexiver Modernisierung, Frankfurt a.M.: Suhrkamp.

Beck, U. and W. Bonß (eds.), (2001), Die Modernisierung der Moderne, Frankfurt a.M.: Suhrkamp.

Bogner, A. and W. Menz (2002), 'Wissenschaftliche Politikberatung? Der Dissens der Experten und die Autorität der Politik', Leviathan 30: 384-99.

Bonß, W. (1995), Vom Risiko. Unsicherheit und Ungewissheit in der Moderne, Hamburg: Hamburger Edition.

Bundeskanzleramt (ed.), (2001), 'Verordnung des Bundeskanzlers über die Einsetzung einer Bioethikkommission', Bundesgesetzblatt für die Republik Österreich vom 29.06.2001, pp. 1283-4.

Crozier, M. and E. Friedberg (1977), L'acteur et le système: Les contraintes de l'action collective, Paris: Seuil.

Friedberg, E. (1993), Le pouvoir et la règle, Paris: Seuil.

Friedberg, E. (2003), 'Mikropolitik und organisationelles Lernen', in H. Brentel, H. Klemisch and H. Rohn (eds.), Lernendes Unternehmen. Konzepte und Instrumente für eine zukunftsfähige Unternehmens- und Organisationsentwicklung, Wiesbaden: Westdeutscher Verlag, pp. 97-108.

Gmeiner, R. and U. Körtner (2002), 'Die Bioethikkommission beim Bundeskanzleramt - Aufgaben, Arbeitsweise, Bedeutung', Recht der Medizin 9: 164-73.

Gottweis, H. (2001), 'Die unsichtbare Kommission', Der Standard, 13.12.2001.

Habermas, J. (1971), 'Vorbereitende Bemerkungen zu einer Theorie der kommunikativen Kompetenz', in J. Habermas and N. Luhmann (eds.), Theorie der Gesellschaft oder Sozialtechnologie. Frankfurt a.M.: Suhrkamp, pp. 101-41.

Japp, K.P. (1992), 'Selbstverstärkungseffekte riskanter Entscheidungen. Zum Verhältnis von Rationalität und Risiko', Zeitschrift für Soziologie 21: 31-48.

Japp, K.P. (1996), Soziologische Risikoforschung - Funktionale Differenzierung, Politisierung und Reflexion, Weinheim and München: Juventa.

Joss, S. and J. Durant (eds.), (1995), Public participation in science: the role of consensus conferences in Europe, London: Science Museum Press.

Joss, S. and H. Torgersen (2002), 'Implementing participatory technology assessment - From import to national innovation', in S. Joss and S. Bellucci (eds.), Participatory Technology Assessment. European perspectives, London: Centre for the Study of Democracy, pp. 157-87

Kuhlmann, A. (2002), 'Kommissionsethik. Zur neuen Institutionalisierung der Moral’, Merkur 56: 26-37.

Küpper, W. and A. Felsch (1999), Organisation, Macht und Ökonomie - Mikropolitik und die Konstitution organisationaler Handlungssysteme, Wiesbaden: Westdeutscher Verlag.

Küpper, W. and G. Ortmann (eds), (1992), Mikropolitik: Rationalität, Macht und Spiele in Organisationen, Opladen: Westdeutscher Verlag.

Latour, B. (1999), Pandora's Hope: Essays on the Reality of Science Studies, Cambridge and London: Harvard University Press.

Luhmann, N. (1991), Soziologie des Risikos, Berlin and New York: de Gruyter.

Luhmann, N. (1992), Die Wissenschaft der Gesellschaft, Frankfurt a.M.: Suhrkamp.

Nowotny, H., P. Scott, and M. Gibbons (2001), Re-Thinking Science. Knowledge and the Public in an Age of Uncertainty. Cambridge: Polity Press.

Nullmeier, F., T. Pritzlaff and A. Wiesner (2003), Mikro-Policy-Analyse. Ethnographische Politikforschung am Beispiel der Hochschulpolitik, Frankfurt a.M. and New York: Campus.

Ortmann, G., A. Windeler, A. Becker and H.J. Schulz (1990), Computer und Macht in Organisationen Mikropolitische Analysen, Opladen: Westdeutscher Verlag.

Schelsky, H. (1965), 'Der Mensch in der wissenschaftlichen Zivilisation', in H. Schelsky (ed.), Auf der Suche nach der Wirklichkeit. Gesammelte Aufsätze, Düsseldorf and Köln: Diedrichs-Verlag, pp. 43980.

Schüssel, W. (2001), 'Wir brauchen ein Frühwarnsystem für neue wissenschaftliche Entwicklungen', Die Presse, 16.03.2001.

Tacke, V. (2000), 'Das Risiko der Unsicherheitsabsorption. Ein Vergleich konstruktivistischer Beobachtungsweisen des BSE-Risikos’, Zeitschrift für Soziologie 29: 83-102. 
Weber, M. (1958), 'Parlament und Regierung im neugeordneten Deutschland. Zur politischen Kritik des Beamtentums und Parteiwesens', in M. Weber (ed.), Gesammelte Politische Schriften, Tübingen: Mohr, pp. 294-431.

Weingart, P. (2001a), 'Paradoxes of scientific advice to politics', in OECD Proceedings: Social Sciences for Knowledge and Decision Making, pp. 79-94.

Weingart, P. (2001b), Die Stunde der Wahrheit? Zum Verhältnis der Wissenschaft zu Politik, Wirtschaft und Medien in der Wissensgesellschaft, Weilerswirst: Velbrück Wissenschaft.

Willke, H. (2003), Heterotopia. Studien zur Krisis der Ordnung moderner Gesellschaften, Frankfurt a.M.: Suhrkamp.

Winner, L., A. Feenberg and T.H. Nielsen (eds.), (1997), Technology and Democracy: Technology in the Public Sphere, Oslo: Center for Technology and Culture. 